\title{
Research on the Necessity of Rural Education in Central and Western China
}

\author{
Yichi Chen
}

\author{
Zhejiang Wanli University \\ 838856420@qq.com
}

\begin{abstract}
China's rural education has achieved certain results, but it still has many shortcomings compared with urban education. The economic and social conditions of remote villages determine that their educational development cannot be synchronized with coastal cities such as Shanghai, and their educational goals should also be different from those of coastal cities such as Shanghai. At the same time, China's population migration is large, so do rural school-age children migrate to cities with their parents? Is the number of people staying in the countryside gradually decreasing? Is it necessary to increase investment in rural education in China? In this study on the "necessity of rural education in the central and western regions", based on the current situation, difficulties and future development of the rural areas in the central and western regions of China, it is concluded that we must increase investment in education in rural areas, especially in the central and western regions.The conclusion that rural education should be reformed according to local conditions and that rural education should serve the country. The main body of China's compulsory education should be rural students. China's rural education determines the height of the future development of China's education: if China's urban education determines how broad China's education can be, then China's rural education is the decisive factor in how far China's education can go. factor. The number of "left-behind children" in China's rural areas has exceeded 6.97 million. Under these specific conditions, what can we do so that local children can also receive the same education, so that more "township second generations" and "township third generations" "Returning, so that every rural child can enjoy the grace of education at home. This article only does some preliminary analysis of some rural areas in China, and proposes some methods and strategies from the perspective that education reform should be adapted to local conditions and that the purpose of education should be used by the country, so as to provide decision-making basis for governments and business departments at all levels to formulate improvement measures.
\end{abstract}

Keywords: rural education, urban-rural balance, the necessity of rural education, educational purpose , educational reform

\section{INTRODUCTION}

The unbalanced development of China's urban and rural education, and how to accelerate the improvement of rural education quality is still a hot and difficult point in today's Chinese society. It is also a pain point. It is a key link in the gap in the quality of the whole people. From the perspective of social and historical development and the improvement of the cultural quality of the whole people, it is an inevitable choice for history to improve the educational level of rural areas, especially rural areas in the central and western regions. From an economic perspective, the development of rural education in the central and western regions has an inevitable relationship with social and economic development. For human society, exploring how to carry out educational development in inland rural areas is a kind of public welfare social activity. Therefore, it is imperative to explore whether to increase investment in rural education and how to promote rural education.

Looking at the map of China, the land plates in the central and western regions account for more than two-thirds of my country's total land plates. However, taking Heihe-Tengchong as the boundary, the total population of Heihe-Tengchong is less than $30 \%$ of the population to the east. Have all people come to the coastal areas to develop? Should education be developed in sparsely populated areas? With such a small population, is it necessary to develop education?

In order to better understand the issue of whether to 
develop education in the East and the West, this article discusses rural education online such as "New Model of Rural Education: Rural People-oriented Education Practice", "The Choice of 'Trail': A Little Sharing of Charity Entrepreneurship Practice", etc. On the basis of course viewing and learning, we also collected a large amount of literature and conducted online interviews, summarized some domestic examples of rural education promotion and practice in the central and western regions, and analyzed the current situation and existing problems of the education economy and social hardware in the central and western rural areas of China, Proposed that while increasing investment in rural education in the central and western regions, reforming rural education in accordance with local conditions and allowing rural education to serve the countryside is the future development direction of education in the central and western regions of China.

\section{THE CURRENT SITUATION AND DIFFICULTIES OF EDUCATION IN RURAL CHINA}

\subsection{Current status}

\section{1) "Semi-literate" still exists $\lceil 1\rfloor$}

Although China vigorously promotes education, it is illegal to stipulate that school-age children not be sent to nine-year compulsory education in the form of law, but for many reasons, there are still semi-illiterate people in today's society. An illiterate refers to an adult who is illiterate and cannot write. A semi-illiterate is a person who only knows some commonly used Chinese characters and has been studying intermittently for several years. The majority of the semi-illiterate people are elderly people over 60 years old in remote and impoverished areas, especially those born before liberation. Due to the influence of backward feudal thoughts such as "patriarchy of boys" and "women without talents are virtue" before liberation, they only In the post-liberation "literacy campaign", they vaguely learned a few commonly used Chinese characters; there are some people who can go to school but don't want to learn. The adults also pursued the theory of "reading is useless", so they became semi-illiterate.

\section{1) The vicious circle of rural education}

Because the rural areas in the central and western regions are deeply inland, the climatic conditions are bad, and the economy is underdeveloped, the teaching hardware and facilities cannot keep up, and the original teaching foundation is poor; the living conditions in the central and western regions are not as good as those in the eastern coastal cities, and many excellent teachers are unwilling to long-term Taking root in the west, some capitalists feel that the investment income in the local area is worrying, and they are unwilling to try, so the central and western regions invest less resources; rural education is not as good as the eastern region in terms of the teaching force and the teaching hardware facilities. Parents will go out with school-age children and go to the corresponding schools for children of migrant workers. As a result, the loss of students in the central and western regions has gradually accelerated.

\section{2) The crisis of farmers' descendants}

Many offspring of peasants were born in cities. They do not identify with the countryside from the bottom of their hearts, and they have the "three detachments" problem of leaving the country, leaving the farming, and leaving the soil. Studying is really painful for this group of people. When studying, they always find it boring. They think that the knowledge they have learned will not be used in part-time jobs in the future, so they don't want to receive education anymore. The number of this group of people is more than one-tenth of China's total population. In other words, they are the main force in China's social development, but they do not study and are unwilling to learn. Under such circumstances, it is very difficult for China to develop in the future.

\subsection{Difficulty}

2) The content of learning has nothing to do with the work, which leads to students not wanting to learn or unwilling to learn

Learning is a long-term investment, and its results cannot be immediately fed back. Based on this model, some short-sighted rural students think that learning is useless. You have to pay tuition when you go to school, and you can earn money by working part-time. Compared with the two, they feel that if you continue to study for three, five, or ten years, you may not be able to achieve anything. Moreover, they will not engage in scientific research and academic work in the future, so it is better to enter early. The existence of the idea that the society goes to work and earn money to subsidize the family, makes education promotion a difficult.

3) The living conditions in the countryside are not as good as those in the cities, and good teachers are reluctant to go to the countryside

Many rural schools teach in dilapidated houses (Table 1); many rural school students cannot afford the necessary books, and teachers cannot get the necessary teaching materials. The average county teacher's salary is more than one-third more than the township teacher's salary. [2]Therefore, many key teachers in central and western cities have gradually moved to Beijing, Shanghai, Shenzhen and other large cities in the east, while senior teachers in county towns have moved to central cities. According to incomplete statistics, in 2001, Deyang City, Sichuan Province had 61 senior high school teachers outflow.[3] 
Table 1. The number and area of dilapidated teaching houses across China (Incomplete)

\begin{tabular}{|c|c|c|c|c|c|c|c|}
\hline & National Average & Yunnan & Guangxi & Sichuan & Hunan & Guizhou & Henan \\
\hline $\begin{array}{c}\text { Teaching Centers } \\
\text { (Number) }\end{array}$ & 9972 & 97716 & 62612 & 12096 & 5282 & 4827 & 4190 \\
\hline Dilapidated house $\left(\mathrm{m}^{2}\right)$ & 719102 & 3433369 & 1910364 & 1390647 & 988488 & 201755 & 1754423 \\
\hline
\end{tabular}

Source: Compiled based on relevant data of China Education Statistics Yearbook: 2008 [4]

4) Large differences in education investment between urban and rural areas

There is a big gap between urban and rural education mainly in the four aspects of hardware facilities, curriculum settings, funding conditions, and teacher quality. In terms of hardware facilities, in some rural classrooms in the central and western regions, the facilities are very aging, and there are often cases of crashes and failure to attend classes, which affects the order, process and quality of teaching to a large extent. In terms of curriculum, rural schools do not have their own special courses apart from the subject courses prescribed by the state, while urban children can take school-based courses, local courses, and go to museums for field trips. In terms of funding conditions, rural schools often have insufficient funds. When schools want to do something or want to develop some courses, they are powerless. Finally, there is the quality of teachers. For those teachers who are still in the countryside, their thinking mode and the methods and methods used in teaching are also very backward compared to the cities (Table 2, Figure 1).

Table 2. One-semester school funding situation at Longwen Teaching Center in Fengcheng Town, Xinfeng County, Guangdong Province

\begin{tabular}{|c|c|c|}
\hline $\begin{array}{l}\text { Income } \\
\text { (Yuan) }\end{array}$ & \multicolumn{2}{|c|}{$\begin{array}{l}144 \text { (Utilities per student) }{ }^{*} 34 \\
\text { (Student number) }+80 * 7 \text { (Number } \\
\text { of preschool classes) }=5456 \text {, } \\
\text { centralize controlled by the central } \\
\text { school }\end{array}$} \\
\hline \multirow[t]{6}{*}{$\begin{array}{l}\text { Expenditure } \\
\text { (Yuan) }\end{array}$} & Office Supplies & $\begin{array}{l}3000 \\
\text { (Including } \\
\text { Teacher's book, } \\
\text { chalk, etc.) }\end{array}$ \\
\hline & $\begin{array}{l}\text { Entertaining } \\
\text { superior leaders } \\
\text { for inspection }\end{array}$ & 1000 \\
\hline & $\begin{array}{l}\text { Building } \\
\text { maintenance }\end{array}$ & 300 \\
\hline & Sports Equipment & 300 \\
\hline & Utilities & 1200 \\
\hline & $\begin{array}{l}\text { Teaching and } \\
\text { Research } \\
\text { Activities, etc. }\end{array}$ & $\begin{array}{l}500 \\
\text { (Including open } \\
\text { classes, Young } \\
\text { Pioneers } \\
\text { activities, etc.) }\end{array}$ \\
\hline
\end{tabular}



Fig. 1. 2015-2019 urban and rural education investment comparison

\section{WAY OUT}

\subsection{Increase investment in rural education and reform rural education according to local conditions}

\section{1) Policy:}

Rural education should be transformed into the goal of cultivating talents in cities, and rural education should cultivate talents for the countryside.

\section{2) Concept:}

Acknowledge and accept the differences between urban and rural areas, and make full use of the unique resources of the countryside. 


\section{3) Content:}

Rural education must be implanted with the connotation of the countryside, with "life is education" as the core concept, and give full play to the role of nature, so as to "the countryside and the people", so that rural children can enjoy their own good education in their hometowns, which can be used in the future. Good education.

\subsection{Let rural education serve the village}

\section{1) Necessity}

Children in cities and children in rural areas need different education. Urban children may not be able to use the knowledge of planting seedlings and farming all their lives. What they need is academic education in scientific innovation. In the future, they will go more. Do academic management. As for the children in the countryside, they are mostly born in peasant families. Some academic knowledge, such as foreign languages, they don't necessarily need in this life. What they need is some technical knowledge in life to help them in their future work. Can have better competitiveness. Let the village children learn something that is useless for them in the future, but they will find it boring and useless, so they don't want to learn it. Just like the development of culture, we must develop a culture that the public loves to hear, and the same is true for the development of rural education. We must develop the education that the village needs and provide talents for the development of the village.

\section{2) Feasibility}

In fact, many parents in poverty-stricken areas still attach great importance to education. Take Zhanma Village as an example. There are several boarding private schools in Zhanma Village. The tuition fees of these schools are more expensive than other public schools, but the quality of teaching will still be great. To improve, parents who have a little bit of conditions will send their children to study. However, in elementary school, there are still many children at home. The mothers of these children usually choose to stay at home to accompany their children to study, and there are relatively few who really only live with their grandparents. Comrade Present $\mathrm{Xi}$ put forward that "Prevention of economy and mind" was proposed, and the establishment of a basic model of education for poverty alleviation that combined "helping the will" and "helping the intelligence" emphasized that the development of rural basic education should be taken as an important starting point for poverty alleviation through education, and great efforts should be made. The development of vocational education is the main focus of educational poverty alleviation.[5]

\section{3) Measures}

\section{Carry out diversified small class teaching}

The number of rural students is not as high as that in cities, and the number of teachers and teaching hardware in rural areas are still insufficient. This requires us to integrate rural educational resources. In the context of rural small classes, try to develop hierarchical teaching and implement the strategy of activity teaching. Although the small-class teaching theory of rural teaching has been proposed very early, it has not been fully implemented. Diversified small-class teaching is based on the reality of rural education, but also focuses on the long-term. While improving the quality of education and teaching in the vast rural areas, it can further promote the balanced development of my country's urban and rural education.[6] Many children in rural areas are still very sensitive to inferiority complex. Small-class teaching can take into account the psychology of these students and promote the healthy development of students' body and mind.

Carry out local characteristic courses such as workshops

Carry out corresponding courses in accordance with local industrial characteristics and local conditions. For example, "Reading in Sunny and Rainy Day": I work in the outdoor industry when it is sunny, and when it rains, everyone sits together and learns the traditional skills of this industry. Take Qianfeng District as an example. There is Daliang City in Qianfeng District, which is a relic of Anti-Yuan Dynasty. However, this site has not been protected and fully developed. We can organize students to explore the history of Daliang City and make our own publicity for Daliang City. Works and show them.

Conduct regular teaching research and feedback to clarify what students really need.

It is necessary to pursue the concept of "Treating students as relatives and family ". Every semester, questionnaires will be used to investigate students' satisfaction with the course of this semester, and "SUBLATE" teaching; at the same time, students can propose and choose what they want to learn. Appropriate courses will be carried out in the next semester.

\section{CONCLUSION}

Practice is the purpose of understanding. The development of rural education is very difficult. Meager school funding, scarce teaching resources, backward ideas and uncontrollable geological environmental disasters... Everything is doomed to the central and western regions of China. Regional education cannot imitate urban education and can only open up new rural teaching methods. However, whether it is urban 
education or rural education, it must be developed and must be developed. Confucianism once put forward the policy of "teach students in accordance with their aptitude". I think it is good. For rural education, we should not only "teach students in accordance with their aptitude", but more importantly, "teach students in accordance with their aptitude". It does not mean that all education must be achieved. In the same direction, the same goal must be achieved. What is the significance of such a uniform teaching? Mao Zedong once said, "Reading is learning, and using is learning, and it is more important learning." Education that can be applied is good education, effective and necessary education. The direction of development of rural and urban areas is different, and the service targets are also different. If rural education simply imitates the city, then such education can be said to be very blind. Whatever the village needs and what kind of talents are needed, we will cultivate what, and cultivate what kind of talents.

Although rural education in the central and western regions of China needs to develop a separate development model, it cannot be completely left to develop freely. It is necessary to jointly establish and improve the performance appraisal system, which can effectively improve the international competitiveness and innovation ability of characteristic education in rural areas. At the same time, a unified education management standard and rules should be established, unified management with urban education, separate teaching, and regular meetings should be held to discuss teaching policies and choose the fittest. Based on comparative advantages, the transformation and upgrading of the rural education industry structure will be realized, and the comparative advantages of rural education will be transformed into competitive advantages; the government must further develop a good development plan, do a good job in top-level design and strategic deployment, and lead and drive the overall development. In the implementation of the plan, we must insist on having laws to follow, we must adhere to laws, we must adhere to local conditions, maximize strengths and avoid weaknesses, and develop healthily; we must adhere to the synchronization of rural education progress with innovative development, continue to expand the edge of rural education possibilities, and enter new realms; we must adhere to open development Parallel to shared development, strengthen inter-provincial cooperation and counterpart assistance, and strive to create a better new situation and new chapter in the development of rural education in the central and western regions, and realize different rural education innovations in the historical trend of revitalizing China. Spread the Chinese wisdom of a community with a shared future for mankind.

\section{REFERENCES}

[1] Illiteracy in today's world. https://zhidao.baidu.com/question/4639431561640 82245.html? sort=11\&rn=5\&pn=0\#wgt-answers

[2] "On the Ecological Environment of Rural Moral Construction in Backward Areas" Wan Yuanying; "Journal of Southwest University for Nationalities (Humanities and Social Sciences Edition)" 2004, (09): 260-263 Journal of Southwest University for Nationalities (Humanities and Social Sciences Edition)

[3] "The Impact of Low-age Boarding on the Socialization of Rural Pupils"; Liu Xianli; "Chinese Excellent Master's Thesis Full-text Database" 2007, (04): Jilin University

[4] Fan Xianzuo. Fundamental Issues of Rural Education Development [ CSSCI ] [ Peking University Core]. Journal of Central China Normal University (Humanities and Social Sciences Edition). 2015,54(05)

[5]"Research on Xi Jinping Thoughts on Educational Poverty Alleviation" Author: Mu Huitao; "Chinese Doctoral Dissertation Full-text Database" 2019, (09): Northeast Normal University

[6]"Research on Small Class Teaching in Rural Primary Schools"; Chen Yanzhong; "Chinese Excellent Master's Thesis Full-text Database" 2010, (01): Henan University 